УДК 378.016:796:613

DOI https://doi.org/10.26661/2663-5925-2021-2-14

\title{
ПРОБЛЕМА ВИВЧЕННЯ ЗБАЛАНСОВАНОГО ХАРЧУВАННЯ ПРОФЕСІЙНИХ СПОРТСМЕНІВ У СПЕЦІАЛЬНІЙ ЛІТЕРАТУРІ (НА ПРИКЛАДІ ВЕЛИКОГО ТЕНІСУ)
}

\author{
Кіченок Н. В. \\ професійна тенісистка \\ Дніпровський державний інститут фізичної культури і спорту \\ вул. Набережна Перемоги, 10, Дніпро, Україна \\ orcid.org/0000-0001-6646-9846 \\ kichenoknadiia@i.ua
}

\begin{abstract}
Ключові слова: фізична підготовка, тренування, дієта, раціон, теніс, харчування.
\end{abstract}

Стаття присвячена вивченню питання збалансованого харчування професійних спортсменів у спеціальній літературі на прикладі великого тенісу. Фрагментарна висвітленість у літературі дилем збалансованого харчування професійних тенісистів зумовила вибір теми нижченаведеного дослідження. У розвідці висвітлено теоретичні аспекти проблем створення схем збалансованого харчування професійних спортсменів за рекомендаціями різних авторів. Відзначено, що проблема харчування спортсменів не може бути зведена до звичайного відтворення енергії, витраченої під час тренувальної та змагальної діяльності. Акцентовано увагу на тому, що раціон харчування тенісиста залежить від того, на якому етапі підготовки він перебуває. Апробація різних варіантів меню перед тренуванням допомагає визначити, які продукти найкращі для вживання перед змаганням. Детально схарактеризовано потреби в енергії й основних харчових речовинах професійних спортсменів тенісистів. Підкреслено фундаментальну роль раціонального харчування протягом тренувального процесу та виступу безпосередньо на змаганнях. Охарактеризовано особливості спортивного харчування професійних тенісистів, проаналізовано застосування в харчовому раціоні спортсменів різноманітних вітамінних та мінеральних комплексів, наголошено, що використання спортивного харчування не компенсує повною мірою витратиенергіїтапоживних речовин. Проведенийавтороманаліздоводить, що сучасному професійному тенісу притаманні інтенсивні фізичні навантаження, висока нервово-емоційна напруга боротьби, націленість на рекордні спортивні результати. Автором підкреслено, що розподіл добового раціону необхідно здійснювати диференційовано залежно від встановленого розпорядку дня (графік навантажень та відпочинку), описано такі етапи: базовий; передзмагальний; безпосередньо турнір та відновлювальний етап. Наведено переконливі аргументи на користь того, що для кожного тенісиста необхідно складати індивідуальну систему харчування, яка б ураховувала значну кількість важливих чинників, як-от вік, стать спортсмена(ки), інтенсивність тренувань, рівень фізичної підготовки, час на відновлення, низку інших факторів. 


\title{
PROBLEM OF STUDYING THE BALANCED NUTRITION OF PROFESSIONAL ATHLETES IN THE SPECIALIZED LITERATURE (BY THE EXAMPLE OF LAWN TENNIS)
}

\author{
Kichenok N. V. \\ Professional Tennis Player \\ Dnipro State Institute of Physical Culture and Sport \\ Naberezhnaya Peremohy str., 10, Dnipro, Ukraine \\ orcid.org/0000-0001-6646-9846 \\ kichenoknadiia@i.ua
}

Key words: fitness, training, diet, ration, tennis, nutrition.

\begin{abstract}
The article is devoted to the study of a balanced nutrition of professional tennis players in the special literature by the example of lawn tennis. Fragmentary coverage of the problems of balanced nutrition of professional tennis players in the literature determined the choice of the following research topic. The theoretical aspects of the problems of creating balanced nutrition schemes for professional tennis players according to the recommendations of different authors are covered in the study. It is noted that the problem of nutrition of sportsmen can't be reduced to the normal reproduction of energy expended during training and competitive activity. It is emphasized that a tennis player's diet depends on the stage of preparation. Approbation of various variants of the menu before training helps to determine which foods are the best to eat before competition. The requirements for energy and basic nutrients of professional tennis players are characterized in detail. The fundamental role of rational nutrition during the training process and directly at the competitions is emphasized. The features of sports nutrition of professional tennis players are characterized, the use of different vitamin and mineral complexes in the diet of sportsmen is analyzed, it is noted that the use of sports nutrition does not fully satisfy the energy and nutrient requirements. The author's analysis draws attention to the fact that modern professional tennis is characterized by intense physical exertion, high nervous and emotional stress of the struggle, the focus on record sports results. The author emphasizes that the distribution of the daily ration should be differentiated depending on the established daily schedule (schedule of loads and rest), the following stages are described: basic, pre-competition, the tournament itself and the recovery stage. Convincing arguments are presented, for each tennis player it is necessary to compose an individual system of nutrition which would consider a considerable quantity of important factors, such as age, sex of the sportsman, training intensity, level of physical preparation, time for recovery and some other factors.
\end{abstract}

Постановка проблеми. Сучасному професійному тенісу притаманні інтенсивні фізичні навантаження, висока нервово-емоційна напруга боротьби, націленість на рекордні спортивні результати. Для тенісистів-спортсменів збалансоване харчування є вкрай важливим, адже останнє забезпечує витривалість та допомагає витримати тривале протистояння на корті. Неодмінно майже кожен спортсмен стикається 3 типовою дилемою - зниження працездатності внаслідок нерегулярного прийому їжі та незбалансованого харчування. Проблеми, пов'язані з харчуванням, зазвичай виникають у зв'язку з недостатнім споживанням рідини та вуглеводів, що зумовлює зниження швидкості, погіршуються показники витривалості, концентрації уваги й інших визначальних критеріїв ефективної фізичної працездатності професійного тенісиста. На превеликий жаль, як свідчать особисті спостереження, спортсмени нехтують прямим зв'язком між необхідною концентрацією та виконанням ігрових рухів та кількістю вуглеводів в організмі. Досвід демонструє, що досить часто тенісисти вже під час змагань розпочинають вживати будь-які вуглеводовмісні продукти харчування або рідини тільки після появи стійкого відчуття втоми. Важливо розуміти, що вуглеводи повинні бути складними, тобто полісахаридами, засвоюються останні досить повільно, тому підтримують кількість АТФ на потрібному рівні тривалий час, 3 іншого 
боку - такими, щоб надмірно не перевантажувати печінку та підшлункову залозу. Варто наголосити, що професійний теніс - це один із найбільш виснажливих видів спорту. Перемоги зумовлені не лише талантом чи багаторічними тренуваннями та реалізацією набутих умінь, а й індивідуальними планами харчування. Небажані втрата або набір ваги також можуть бути наслідком хаотичного вибору продуктів харчування. Організоване планування сприятиме уникненню цих проблем та забезпечить оптимальну працездатність. Вибір «правильних» продуктів $\epsilon$ важливим для спортивного успіху, як і володіння найбільш відповідною тренувальною програмою. Хоча збалансований раціон не гарантує атлетичного успіху, варто розуміти, що незбалансоване харчування може звести нанівець увесь тренувальний процес. Більшість спортсменів досягають високих результатів завдяки систематизації. Тобто в досліджуваному нами питанні відсутні універсальні підходи, і ми вважаємо, що їх розроблення на практиці не $\epsilon$ виправданим. Це зумовлено тим, що для кожного тенісиста необхідно складати індивідуальну систему харчування, яка б враховувала значну кількість важливих чинників, як-от вік, стать спортсмена(ки), інтенсивність тренувань, рівень фізичної підготовки, час на відновлення тощо. Також професійний тенісист повинен бути компетентним у питаннях збалансованого харчування, уміти самостійно внести корективи в разі зміни, наприклад, графіка проведення турніру. Зауважимо, повсюдним явищем $є$ перенесення ранкових матчів на вечір або інший час доби, що корелює 3 особливими вимогами до харчування тенісиста. Від того, наскільки збалансованим буде раціон спортсмена, залежать й успіх його виступів та користь від тренувань, зважати на цей чинник рекомендується як професіоналам, так і новачкам. Професіоналам значно легше, бо досвід, накопичений попередніми поколіннями спортсменів, тренерів та дієтологів, дає можливість відразу ж прописати оптимальне меню й обрати найбільш зручний режим харчування. Найчастіше спортсмен просто дотримується рекомендацій, які для нього розробляє тренер після консультації з дієтологом. Тенісист-початківець може зіткнутися 3 низкою перепон, однією 3 них $є$ дефіцит знань, адже послуги спортивних дієтологів не всім доступні, тому інформацію зазвичай беруть із спортивних журналів, інтернету, а іii, наголосимо, потрібно ретельно аналізувати. У навчально-тренувальному процесі підготовки професійних спортсменів проблемі збалансованого харчування приділяється досить уваги, проте у великому тенісі цей визначальний чинник спортивної підготовки часто залишається поза увагою та практично не враховується, на противагу детальним розвідкам аналізу методик загальної фізичної підготовки тенісистів до змагань. Фрагментарна висвітленість у літературі дилем збалансованого харчування професійних тенісистів зумовила вибір теми нашого дослідження.

Аналіз останніх досліджень і публікацій. На думку експертного співтовариства, консолідованого керівним органом олімпійського руху, саме раціональне харчування забезпечує: оптимізацію ефектів тренувального процесу; зниження ризику отримання травм, перетренованості, втоми та хвороб; поліпшення відновлення як між тренувальними сесіями, так і між змаганнями; гарантує впевненість у значній готовності до конкурентної боротьби; підтримку маси та пропорцій тіла; реалізацію ключових переваг для зміцнення здоров'я корисних компонентів їжі [17]. Проблема вивчення раціонального харчування й підтримки водного балансу представлена в дослідженнях М. Кручаниці й інших [14]. Автори детально розкривають загальні питання харчування, описують загальні рекомендації харчування спортсменів [14]. Ми погоджуємося із твердженнями авторів, що «раціональне харчування $\epsilon$ необхідною передумовою успішної підготовки спортсменів протягом тренувального процесу та виступу на змаганнях» [14]. У дослідженні П. Горюк проаналізовано важливість раціонального харчування протягом тренувального процесу та виступу на змаганнях [4]. Як налогошують О. Лебедин і С. Табінська, «удосконалення навчально-тренувального процесу клаліфікованих тенісистів можливе в разі реалізації індивідуального та диференційованого підходу у спортивній підготовці» [10]. Як слушно зауважують Ф. Опанасюк і Г. Грибан, «проблема харчування студентів-спортсменів не може бути зведена до звичайного відтворення енергії, витраченої під час тренувальної та змагальної діяльності». Учені підготували методичні розробки гігієни та харчування спортсменів, розкрили спеціальні питання в системі харчування спортсменів, акцентували увагу наукової спільноти на фундаментальній ролі білків, вуглеводів, жирів, вітамінів та мінеральних речовин у харчуванні спортсмена [12]. Медико-біологічні засоби відновлення, зокрема раціональне харчування під час окремих тренувальних занять, змагань, у проміжках між заняттями та змаганнями, на окремих етапах річного циклу підготовки описала М. Ібраімова [6]. Дослідниця запевняє, що «система профілактично-відновлювальних заходів повинна реалізовуватися комплексно 3 використанням засобів психологічно-педагогічного та медикобіологічного впливу». Аналітичний огляд сучасних тенденцій розвитку харчування спортсменів загалом із метою популяризації науково обгрун- 
тованих підходів до побудови адекватних раціонів та включення до них спеціалізованих продуктів харчування здійснив С. Парастаєв [15]. Е. Колеман підкреслює, що збереження працездатності та підвищення спортивних результатів можливе в результаті дотримання індивідуально-оптимальних стратегій харчування [9]. Доречну, на наш погляд, дефініцію поняття «раціональне збалансоване харчування» наведено у статті Р. Валецької [3], згідно з авторським тлумаченням, «раціональне збалансоване харчування спортсменів (від лат. rationalis - «розумний») - це фізіологічно повноцінне харчування, що забезпечує потреби організму людини в енергії й основних поживних речовинах у їх найбільш сприятливому співвідношенні й з урахуванням віку, статі, характеру праці, кліматичних умов тощо». Не можемо не погодитися 3 міркуваннями С. Жукової, що тенісист повинен бути всебічно підготовлений, як фізично, технічно та тактично, так і психологічно. Теніс - це ефективний спосіб удосконалювати не лише тіло, але й внутрішній світ [5]. Особливості гігієнічного забезпечення на заняттях великим тенісом описує Я. Кепська [8]. Під час інтенсивних тренувань важливо враховувати, як запевняє I. Авілова, що процеси анаболізму мають домінувати над процесами катаболізму для досягнення необхідних спортивних результатів [1]. Аналіз сучасного асортименту, споживчих властивостей та цільового призначення спортивного харчування на українському ринку здійснено С. Бреусовою, В. Міщенко та Н. Дорохтей [2]. Авторами проаналізовані та виявлені найпопулярніші виробники харчування для спортсменів, які дотримуються вимог до спеціальних харчових продуктів, а це передусім такі: відсутність у їхньому складі сильнодіючих, наркотичних i отруйних речовин; відсутність рослинної сировини, що не підтверджена розвідками доказової медицини; регламентованість компонентів діючих речовин; відповідність стандартам дієтичного харчування [2]. Учені наголошують, що вітчизняні виробники спортивного харчування, окрім панівного ДелМас, під торговою маркою «Ванситон», представлені на ринку вкрай фрагментарно, а цю нішу переважно займає продукція США та Європи. Отримані авторами результати досліджень акцентують на потенційній можливості достеменного розширення галузі вищевказаного виду продукції українського ринку спортивного харчування. У наукових публікаціях комплексно описані різні аспекти підготовки спортсменів [6;11-13; 15-16], а системних досліджень із питань раціонального та спортивного харчування професійних тенісистів нами не виявлено.
Отже, метою статті $\epsilon$ детальне висвітлення проблеми вивчення збалансованого харчування професійних спортсменів у спеціальній літературі на прикладі великого тенісу.

Виклад основного матеріалу дослідження. Достеменно відомо, від виду спорту, статі, об'єму й інтенсивності навантажень, маси тіла й інших чинників залежать енерговитрати професійних спортсменів. Раціон харчування тенісиста залежить від того, на якому етапі підготовки він перебуває. Цей вид спорту вимагає значної витривалості, тому споживання калорій має повною мірою задовольняти потреби в енергії. Однією 3 фундаментальних особливостей періоду участі у змаганнях $\epsilon$ необхідність підтримання специфічного рівня спеціальної працездатності. Нині існують надійні дієтичні стратегії, які допомагають спортсменам тренуватися та брати участь у змаганнях, реалізуючи максимально свої потенційні можливості. Концептуально харчування для витривалості має грунтуватися на апробованій інформації, що спрямована на досягнення високої спортивної працездатності. Дієтичні рекомендації розробляють із метою усвідомленого підбору для раціону продуктів, які лише сприятимуть реалізації здоров'язбережувальної стратегії підготовки професійного тенісиста, зведуть нанівець ризик виникнення та розвитку низки захворювань, гарантують підтримання працездатності організму загалом і забезпечення необхідними поживними речовинами. Збалансованість є визначальним критерієм, якому має відповідати харчування тенісиста, тобто, у нашому розумінні, дотичне раціональності та різноманітності. Чітко організована та відповідно реалізовано згідно із планом дієта дозволить забезпечити поживними речовинами професійного тенісиста. Остання допомагає відновити сили, підтримувати ріст та розвиток, регулювати метаболізм, нормальний перебіг хімічних реакцій, тобто підтримання гомеостазу загалом. Незважаючи на усталену думку, немає таких харчових домішок або дієт, які могли б перетворити звичайного спортсмена на видатного атлета. Спортсменам і не тільки щодня необхідно задовольняти потреби організму у вуглеводах, жирах, білках, вітамінах, мінералах та воді. Ключова відмінність полягає в тому, що організм спортсмена, який виконує значну фізичну роботу, витрачає зазвичай більше калорій і енергетичних запасів. Раціон харчування спортсменів у зв'язку 3 інтенсивним білковим метаболізмом, участю низки амінокислот в енергетичному обміні повинен містити підвищену кількість білка. Загальна продуктивність, концентрація, координація забезпечуються правильною регуляцією білкового обміну. Важливим аспектом $\epsilon$ те, що інтенсивні фізичні навантаження зумовлюють виникнення 
«робочої гіпоксії», остання спричиняє окислення жирів та накопичення у крові продуктів їхнього метаболізму. У літню пору року й у місцевості, де в повітрі не досить кисню, вміст жирів у раціоні спортсменів необхідно зменшувати, добовий раціон повинен не перевищувати 30\%. Деякі спортсмени вважають, що фруктоза - з усіх цукрів найбільш відповідне джерело енергії, характеризується менш значним викидом інсуліну, на противагу глюкозі. Проте споживання фруктози не покращує показники витривалості, а іноді навіть зумовлює погіршення працездатності. Розробити власноруч вуглеводне меню можна за допомогою «системи взаємозамінності харчових продуктів», що $\epsilon$ першоосновою системи планування харчування, розробленої Асоціацією дієтологів і Асоціацією діабетиків США. Деякі спортсмени тренуються настільки напружено, що споживання належної кількості їжі для задоволення, зокрема вуглеводних потреб, стає майже невирішуваною хронічною проблемою. Це може відбуватися 3 кількох причин. Передусім стрес, спричинений інтенсивними тренуваннями, може погіршити апетит настільки, що спортсмен не зможе вживати необхідну йому кількість продуктів - джерел калорій та вуглеводів. Також відзначимо, що споживання великої кількості продуктів за один прийом може викликати шлунково-кишкові розлади, а це буде перешкоджати нормальному тренувальному процесу. Нарешті, на тренування може йти стільки часу, що на збалансоване харчування часу може просто не залишитися. Найважливішою частиною харчового раціону є вода, яка забезпечує оптимальний перебіг обмінних процесів в організмі, теплорегуляцію, травлення, виведення із сечею продуктів обміну речовин. Для підтримки водного балансу, кислотно-основного стану організму, м'язового скорочення і передачі нервових імпульсів необхідні електроліти (мінеральні речовини), як-от натрій, хлор і калій. Розподіл добового раціону залежно від встановленого розпорядку дня (графік навантажень і відпочинку) варто проводити диференційовано. Виділяють такі етапи: базовий; передзмагальний; безпосередньо турнір, відновлювальний етап. Особливості кожного етапу схарактеризуємо нижче у статті.

Базовий етап. Оскільки теніс відносять до швидкісно-силового виду спорту, спортсменам необхідно забезпечити таке харчування, яке передусім насичене білками. Вуглеводів ж має бути менша кількість, як і жирів. Оптимальним співвідношенням уважають таке: $17-18 \%$ білків, $30 \%$ жирів і не більше $52 \%$ вуглеводів. Зауважимо, методики або формули, які могли б дозволити точно розрахувати необхідну калорійність раціону, не $\epsilon$ регламентованими, тому необхідно іiі визначити самостійно, з урахуванням таких показників, як маса тіла (індекс маси тіла повинен бути в межах норми), відсоток жиру в організмі та тренувальні показники загалом на певних етапах. Теоретичні аспекти проблеми харчування спортсменів, з урахуванням різних періодів фізичного навантаження та видів спорту, вивчала М. Кручаниця й інші. Здійснений авторами аналіз акцентує нашу увагу на тому, що харчування спортсменів має грунтуватися на основоположних принципах [14]:

- «організм повинен бути забезпечений кількістю енергії, що відповідає іiі витраті у процесі виконання фізичних навантажень; харчування збалансованим відповідно до інтенсивності фізичних навантажень;

- періоди інтенсивних і тривалих фізичних навантажень, безпосередньої підготовки до змагань, самих змагань і наступного відновлення мають супроводжуватися вибором адекватних форм харчування (продукти, харчові речовини та їх комбінації);

- залежно від антропометричних, фізіологічних і метаболічних характеристик спортсмена, стану його травної системи, особистих смаків і звичок має складатися індивідуальний план харчування;

- для активізації та регуляції метаболічних процесів організму доцільним $\epsilon$ використання харчових речовин;

- використання широкого асортименту продуктів і застосування різних прийомів їх кулінарної обробки для оптимального забезпечення організму необхідними харчовими речовинами;

- включення в раціони біологічно повноцінних та швидко перетравлюваних продуктів і страв, що не переобтяжують травної системи» [14].

Апробація різних варіантів меню перед тренуванням допомагає визначити, які продукти найкраще підходять до вживання перед змаганням. Не варто споживати невипробувані продукти або рідини безпосередньо перед змаганням. Тенісистам насамперед необхідно враховувати те, що під час гри неминучим $\epsilon$ підняття загальної температури тіла. Єдиний спосіб боротьби із цим процесом - активне потовиділення, але водночас може настати зневоднення, що зумовить передчасну втому. Щщоб уникнути таких небажаних наслідків, рекомендується споживати від 0,5 до 1 літра води під час змагання тривалістю приблизно дві години. Щоби забезпечити м'язи додатковими джерелами енергії, можна готувати енергетичний напій самостійно, або купувати готовий. Важливо розуміти, що використання спортивного харчування не задовольняє повною мірою витрат енергії та поживних речовин. Постійно підтримувати та підвищувати спортивну працездатність, стимулювати процеси відновлення після змагань і тренувань допоможе лише збалансоване повно- 
цінне харчування. Наголосимо, що стимулюючі речовини покращують результати тільки на час діiі, тому їх рекомендують приймати тільки перед змаганнями. У звичайні тренувальні дні варто уникати стимуляторів, адже вони можуть бути однією із причин відчуття хронічної втоми через постійні фізичні навантаження, тобто перетренованості.

Передзмагальний етап характеризується тим, що перед тенісистом постає низка завдань, саме тому харчування має бути особливим. Важливим $\epsilon$ оптимальне насичення субстратами енергетичного типу, елементами мінерального походження та мікроелементами, а саме цинком та залізом. Не менш важливим $€$ забезпечення організму вітамінним комплексом. Змінюється частота прийомів їжі, яка повинна бути насичена білками. Це сприятиме підвищенню швидкісних та силових якостей професійного тенісиста. На передзмагальному етапі з меню тенісиста видаляють такі продукти, які містять вуглеводи, водночас рекомендують більше вживати продуктів, що містять клітковину. Споживання фруктів і овочів на вищенаведеному етапі підготовки є пріоритетним. Гарантією готовності до змагань $\epsilon$ в межах норми або підвищена кількість глікогену в м'язах та печінці. Це досягається шляхом зниженням обсягу й інтенсивності тренувань за тиждень до змагань, або збільшенням споживання вуглеводів, допустимим є поєднання цих шляхів.

Eman змагання. Перед початком випробувань тенісистові варто вживати їжу з підвищеним вмістом калорій. Порції повинні бути невеликими і добре засвоюваними. Повноцінні білки та вуглеводи, продуктів, у яких є жири, варто уникати. Варто зауважити, що тренуватися та виступати на змаганнях натщесерце неприпустимо, приймати їжу теж не варто (окрім спеціальних харчових препаратів) безпосередньо перед спортивним навантаженням, оскільки погіршується ії перетравлювання, а наповнений шлунок утруднює діяльність дихальної та серцево-судинної систем.

Відновлювальний етап. Останній етап полягає в тому, що необхідно оновити запаси нутрієнтів, необхідних організму, усунути результати обміну речовин, що безпосередньо пов'язані з активною м'язовою роботою. Тому вітаміни рекомендовано для вживання. Уживати варто такі продукти, у яких високий вміст натрію.

Отже, оскільки раціон тенісиста безпосередньо відображається на активності та працездатності, варто приділяти цьому аспекту особливу увагу. Приблизні раціони розроблені проф. А. Лаптєвим і А. Кареліним [7]. У процесі проведення аналізу джерельної бази ми не знайшли розвідок, які б стосувалися аналізу та корекції наслідків змін харчування внаслідок дії передменструального синдрому спортсменок-тенісисток.
Наша цікавість пов'язана передусім із його впливом на фізичну працездатність. Варто зауважити, що досить поширений такий феномен - найліпші результати демонструються в менструальній фазі, а найгірші - у передменструальній. Обгрунтуванням $є$ затримка рідини в організмі в передменструальній фазі та зниження іiї вмісту під час менструації. Для корекції передменструального синдрому розробляють різноманітні дієтичні схеми із вживанням хлористого натрію, споживанням вуглеводів. Згідно 3 індивідуальними біохімічними клінічними показниками, для уникнення ризику залізодефіциту рекомендований прийом додаткової кількості заліза, особливо в періоди напружених тренувань. Отже, раціональне харчування сприяє підвищенню спортивної працездатності, iï відновленню після інтенсивних навантажень, розвитку скелетних м'язів і нормалізації обміну речовин в організмі, розширює межі пристосування до фізичного і нервового напруження. Воно $\epsilon$ необхідною передумовою успішної підготовки спортсменів протягом тренувального процесу та виступу на змаганнях, характеризується оптимальним співвідношенням білків, жирів та вуглеводів, також вітамінів і мінеральних речовин.

Висновки і перспективи подальших розробок у цьому напрямі. Аналіз наукової літератури iз проблеми вивчення збалансованого харчування доводить необхідність нових наукових досліджень підготовки професійних тенісистів. Ми вважаємо доцільним подальше дослідження та вивчення даної проблеми. Нами було проаналізовано ефективність низки програм збалансованого харчування. Отже, можемо зробити висновок, що для кожного тенісиста потрібно складати індивідуальну схему харчування, яка б ураховувала значну кількість важливих чинників, як-от вік, стать спортсмена(ки), інтенсивність тренувань, рівень фізичної підготовки, час на відновлення тощо. Підтвердженням висновку $\epsilon$ результат нашого спостереження, що стосувався специфіки фізичної підготовки, яка має прикладно-функціональний характер, до високорівневих навантажень. За результатами констатувального експерименту нами були розроблені методичні комплекси для використання у фізичній підготовці юних тенісистів протягом періоду участі у змаганнях. Наголошуємо, харчування спортсмена повинно плануватися так само ретельно, як і саме тренування. Потенційним джерелом проблем є відсутність планування, це твердження, беззаперечно, ми вважаємо аксіомою.

Перспективи подальших досліджень. У наступних дослідженнях плануємо визначити вплив різних компонентів спортивного харчування на досягнення та процеси відновлення професійних тенісистів. 


\section{ЛITЕРАТУРА}

1. Авилова И. Особенности пищевого рациона спортсменов игровых видов. Региональный вестник. 2020. №. 16. С. 29-30.

2. Бреусова С., Міщенко В., Дорохтей Н. Дослідження споживчих характеристик спортивного харчування. Формування національної лікарської політики за умов впровадження медичного страхування: питання освіти, теорії та практики : матеріали V Всеукраїнської науково-освітньої інтернет-конференції, м. Харків, 12-13 березня 2019 р. Харків : НФаУ, 2019. С. 215-217.

3. Валецька Р. Раціональне збалансоване харчування спортсменів. Фізичне виховання, спорт $і$ культура здоров’я в сучасному суспільстві. 2013. № 2. С. 98-101.

4. Горюк П. Особливості збалансованого та спортивного харчування у панкратіоні. Молодий вчений. 2018. № 3.3. С. 103-106.

5. Жуков С., Жуков С. Большой теннис: влияние тенниса на организм человека. Актуальныле научные исследования в современном мире : материалы XXX Международной научной конференции, г. Переяслав-Хмельницкий, 26-27 октября 2017 г. Переяслав-Хмельницкий, 2017. Вып. 10 (30). Ч. 2. С. $70-75$.

6. Ібраімова М. Теніс : навчальна програма для дитячо-юнацьких спортивних шкіл, спеціалізованих дитячо-юнацьких шкіл олімпійського резерву, шкіл вищої спортивної майстерності та спеціалізованих навчальних закладів спортивного профілю. Київ : Федерація тенісу України, 2012. 159 с.

7. Касьянов Г., Евсюков С. Концепция разработки продуктов питания для спортсменов. Современные аспекты производства и переработки сельскохозяйственной продукции. 2019. С. 291-295.

8. Кепская Я. Особенности гигиенического обеспечения при занятиях большим теннисом. Инноватика сегодня. 2020. № 2. С. 3-13.

9. Колеман Э. Питание для выносливости. Пер. с англ. Мурманск : Тулома, 2005. 192 с.

10. Лебедин О., Табінська С. Контроль в управлінні системою підготовки тенісистів. Спорт та сучасне суспільство : матеріали XI Міжнародної наукової інтернет-конференції, 29 березня 2018 р. / НУФВСУ. Київ : Олімпійська література, 2018. С. 63-65.

11. Аспекты эффективности и успешности соревновательной деятельности теннисистов / А. Мингалимова и др. Педагогико-психологические и медико-биологические проблемы физической культуры и cnopma. 2020. №. 15 (4). C. 13-20. DOI: 10.14526/2070-4798-2020-15-4-13-20.

12. Опанасюк Ф., Грибан Г. Гігієна та харчування спортсмена : методичні рекомендації. Житомир : Держ. агроеколог. ун-т, 2004. $31 \mathrm{c.}$

13. Особенности питания и водно-питьевого режима спортсменов игровых видов спорта / Н. Денисова и др. Современные вопросы биомедицины. 2018. Т. 2. №. 4. С. 52-63.

14. Основи харчування : підручник / М. Кручаниця та ін. Ужгород : Вид-во УжНУ «Говерла», 2019. $252 \mathrm{c}$.

15. Парастаев С. Питание спортсменов. Рекомендации для практического применения (на примере футбола). Москва : ООО «Издательство «Спорт»», 2018. 103 с.

16. Полиевский С., Ямалетдинова Г. Питание спортсменов. Функциональность и безопасность пищевых продуктов : учебное пособие для среднего профессионального образования. 2-е изд., испр. и доп. Москва : Юрайт, 2020. 122 с.

17. IOC Consensus Statement on Sports Nutrition. Lausanne, 27 October, 2010. URL: https://stillmed.olympic. org/Documents/Reports/EN/CONSENSUS-FINAL-v8-en.pdf (дата звернення: 17.03.2021).

\section{REFERENCES}

1. Avilova I.A. (2020). Osobennosti pishhevogo raciona sportsmenov igrovyh vidov [Features of the diet of athletes of game types]. Regional bulletin. Vol. 16. P. 29-30.

2. Breusova S.V., Mishchenko V.I., Dorokhtei N.I. (2019). Doslidzhennia spozhyvchykh kharakterystyk sportyvnoho kharchuvannia [Research of consumer characteristics of sports nutrition]. Formation of national medical policy under the conditions of introduction of medical insurance: questions of education, theory and practice: materials V All-Ukrainian Scientific and Educational Internet Conference, (Kharkiv, March 12-13, 2019). Kharkiv: NUPh. P. 215-217.

3. Valetska R.O. (2013). Ratsionalne zbalansovane kharchuvannia sportsmeniv [Rational balanced nutrition of athletes]. Physical education, sports and health culture in modern society. Vol. 2. P. 98-101.

4. Horiuk P.I. (2018). Osoblyvosti zbalansovanoho ta sportyvnoho kharchuvannia u pankrationi [Features of balanced and sports nutrition in pankration]. Young scientist. 2018. № 3.3. P. 103-106.

5. Zhukov S.N., Zhukov S.M. (2017). Bol'shoj tennis: vlijanie tennisa na organizm cheloveka [Tennis: the impact of tennis on the human body]. Actual scientific research in the modern world: materials 
XXX Intern. scientific. conf. (Pereyaslav-Khmelnitsky, October 26-27, 2017). Pereyaslav-Khmelnitsky, Issue. 10 (30), Part 2. P. 70-75.

6. Ibraimova M.V. (2012). Tenis: navchalna prohrama dlia dytiacho-yunatskykh sportyvnykh shkil, spetsializovanykh dytiacho-yunatskykh shkil olimpiiskoho rezervu, shkil vyshchoi sportyvnoi maisternosti ta spetsializovanykh navchalnykh zakladiv sportyvnoho profiliu [Tennis: curriculum for children's and youth sports schools, specialized children's and youth schools of the Olympic reserve, schools of higher sportsmanship and specialized educational institutions of sports profile]. Kyiv: Tennis Federation of Ukraine. $159 \mathrm{p}$.

7. Kas'janov G.I., Evsjukov S.V. (2019). Koncepcija razrabotki produktov pitanija dlja sportsmenov [The concept of developing food for athletes]. Modern aspects of production and processing of agricultural products. P. 291-295.

8. Kepskaja Ja.A. (2020). Osobennosti gigienicheskogo obespechenija pri zanjatijah bol'shim tennisom [Features of hygienic provision when playing tennis]. Innovation today. № 2. P. 3-13.

9. Koleman Je. (2005). Pitanie dlja vynoslivosti [Nutrition for endurance]; per. from English. Murmansk: Tuloma Publishing House.

10. Lebedyn O., Tabinska S. (2018). Kontrol v upravlinni systemoiu pidhotovky tenisystiv [Control in the management of the tennis training system]. Sport and modern society: materials of the XI International Scientific Internet Conference on March 29, 2018; NUFVSU. Kyiv: Olympic Literature. P. 63-65.

11. Mingalimova A.R., Mutaeva I.Sh., Konovalov I.E., \& Gizatullina Ch.A. (2020). Aspekty jeffektivnosti i uspeshnosti sorevnovatel'noj dejatel'nosti tennisistov [Aspects of the effectiveness and success of the competitive activity of tennis players]. Pedagogical-psychological and medical-biological problems of physical culture and sports, № 15 (4). P. 13-20. DOI: 10.14526/2070-4798-2020-15-4-13-20.

12. Opanasiuk F.H., Hryban H.P. (2004). Hihiiena ta kharchuvannia sportsmena: metod. rekomendatsii [Hygiene and nutrition of the athlete: a method. recommendations]. Zhytomyr : State. agroecologist. un-t, $31 \mathrm{p}$.

13. Denisova N.N. et al. (2018). Osobennosti pitanija i vodno-pit'evogo rezhima sportsmenov igrovyh vidov sporta [Peculiarities of nutrition and water-drinking regime of sportsmen of game kinds of sports]. Modern issues of biomedicine. Vol. 2. № 4. P. 52-63.

14. Kruchanytsia M.I., Myroniuk I.S., Rozumykova N.V., Kruchanytsia V.V., Brych V.V., \& Kish V.P. (2019). Osnovy kharchuvannia: pidruchnyk [Basics of nutrition: a textbook]. Uzhhorod: Uzhhorod National University Publishing House "Hoverla". 252 p.

15. Parastaev, S.A. (2018). Pitanie sportsmenov. Rekomendacii dlja prakticheskogo primenenija (na primere futbola) [Nutrition for athletes. Recommendations for practical application (on the example of football)]. Moscow: LLC Publishing House "Sport", 103 p.

16. Polievskij S.A., Jamaletdinova G.A. (2020). Pitanie sportsmenov. Funkcional'nost'i bezopasnost' pishhevyh produktov : uchebnoe posobie dlja srednego professional'nogo obrazovanija [Nutrition for athletes. Functionality and food safety: a textbook for secondary vocational education]. 2'nd ed. Moscow: Yurayt Publishing House, $122 \mathrm{p}$.

17. IOC Consensus Statement on Sports Nutrition. Lausanne, 27 October, 2010. URL: https://stillmed.olympic. org/Documents/Reports/EN/CONSENSUS-FINAL-v8-en.pdf (Last accessed: 17.03.2021). 